DOI $10.5012 /$ bkcs.2011.32.3.800

\title{
Novel Silver(I) Ion Selective PVC Membrane Electrode Based on the Schiff Base $\left(N^{2} E, N^{2} E\right)-N^{2}, N^{2}$-Bis(Thiophen-2-ylmethylene)-1,1'-Binaphthyl-2,2'-Diamine
}

\author{
Eunseon Jeong, Mohammad Shamsuddin Ahmed, Haesang Jeong, Eunhee Lee, and Seungwon Jeon" \\ Department of Chemistry and Institute of Basic Science, Chonnam National University, Gwangju 500-757, Korea \\ *E-mail: swjeon@chonnam.ac.kr \\ Received October 25, 2010, Accepted December 26, 2010
}

\begin{abstract}
A potentiometric sensor based on the Schiff base $\left(N^{2} E, N^{2} E\right)-N^{2}, N^{2}$-bis(thiophen-2-ylmethylene)-1, 1'binaphthyl-2,2'-diamine has been synthesized and explored as an ionophore PVC-based membrane sensor selective for the silver $\left(\mathrm{Ag}^{+}\right)$ion. Potentiometric investigations indicate a high affinity of this receptor for the silver ion. Seven membranes have been fabricated with different compositions, with the best performance shown by the membrane with an ionophore composition (w/w) of: $1.0 \mathrm{mg}$, PVC: $33.0 \mathrm{mg}$, DOA: $66.0 \mathrm{mg}$ in $1.0 \mathrm{~mL}$ THF. The sensor worked well within a wide concentration range of $1.0 \times 10^{-2}$ to $1.0 \times 10^{-7} \mathrm{M}$, at $\mathrm{pH} 5$, at room temperature (slope $57.4 \mathrm{mV} / \mathrm{dec}$.), and with a rapid response time of $9 \mathrm{~s}$; the sensor also showed good selectivity towards the silver ion over a huge number of interfering cations, with the highest selectivity coefficient for $\mathrm{Hg}^{2+}$ at -3.7 . Thus far, the best lower detection limit was $4.0 \times 10^{-8} \mathrm{M}$.
\end{abstract}

Key Words : Schiff base, Silver-ion selective electrode, Potentiometry, Ionophore, PVC membrane

\section{Introduction}

The adverse effects of chronic exposure to silver are a permanent bluish-gray discoloration of the skin (argyria) or eyes (argyrosis). Most studies discuss cases of argyria and argyrosis resulted primarily from exposure to soluble forms of silver. Besides argyria and argyrosis, exposure to soluble silver compounds may produce other toxic effects, including liver and kidney damage, irritation of the eyes, skin, respiratory, and intestinal tract, and changes in blood cells. Metallic silver, however, appears to pose a minimal risk to health. ${ }^{1}$ Silver is used widely in different industries such as coins, jewelry, alloys, electrical devices, and mirrors. Furthermore, many silver based chemicals are used in photographic processes and research, as well as in the production of dental amalgams and burn creams due to its antibacterial properties. $^{2}$ Thus, there exists a high probability of surface and underground water contamination. Accordingly, there exist several techniques for silver metal ion determination, such as thermometric titration, ${ }^{3}$ flame atomic absorption spectroscopy (FAAS), ${ }^{4}$ inductively coupled plasma-atomic emission spectroscopy (ICP-AES), ${ }^{5}$ and inductively coupled mass spectroscopy (ICP-MS); ${ }^{6}$ nonetheless, all these methods are time consuming, involving sample manipulation, and are relatively expensive. Potentiometric sensors based on an ion-selective electrode (ISE) are a typical example of chemical sensors that use the principle of molecular recognition chemistry. They are readily prepared by immobilizing host molecules capable of recognizing a specific class of ionic species in an appropriate polymeric matrix system, which are then built upon an electrode body. In the last three decades, because of their ease of preparation and simplicity of use, ISEs have not only been practical solutions to a wide variety of analytical problems, but also useful tools for probing host-guest chemistry. ${ }^{7}$ The ISE is an ion analysis technique that provides many unique characteristics, such as selectivity, sensitivity, (LODs of subnanomolar or subfemtomolar levels), good precision, simplicity, and low cost. ${ }^{8-12} \mathrm{~A}$ number of silver selective sensors based mainly on Schiff bases, ${ }^{13}$ podands, ${ }^{14}$ cyclams, ${ }^{15}$ calixarenes, ${ }^{16}$ and polystyrene $^{17}$ have been developed. A typical ISE may have a response to ion activity changes in the aqueous phase ${ }^{18}$ based on measurements of the phase boundary potential at the sample/membrane interface. The ionophore is an integral component of the polymeric membrane of an ion selective electrode. The ionophore selectivity over the interfering ion is the concerning issue in ionophore discovery. Good selectivity results from a stronger complex between the ionophore and detecting ion, rather than a weaker complex of the ionophore and interfering ions. ${ }^{19}$ It is well known that sulfurand nitrogen-containing ligands prefer to bind with heavy metal ions such as $\mathrm{Ag}^{+20}$

The present study deals with the Schiff base $\left(N^{2} E, N^{2} E\right)$ $N^{2}, N^{2}$-bis(thiophen-2-ylmethylene)-1,1'-binaphthyl-2,2'-diamine based ISE for selective determination of silver. This PVC membrane ion selective electrode shows a good response towards silver ions, and demonstrates an improved detection limit, response time and slope.

\section{Experimental}

Reagents. The Schiff base $\left(N^{2} E, N^{2} E\right)-N^{2}, N^{2}$-bis(thiophen2-ylmethylene)-1,1'-binaphthyl-2,2'-diamine tested as a carrier of silver ions was synthesized according to a similar procedure described previously. ${ }^{21}$ The precipitate was collected from ether by filtration. The product was recrystallized from ethanol and dried under reduced pressure at $40{ }^{\circ} \mathrm{C} ; 90 \%$ yield, as shown in Figure 1. High molecular weight PVC, 2- 


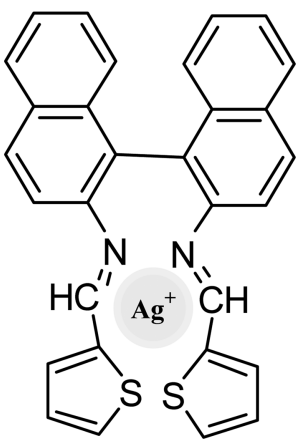

Figure 1. The proposed structure of $\left(N^{2} E, N^{2} E\right)-N^{2}, N^{2}$-bis(thiophen2-ylmethylene)-1,1'-binaphthyl-2,2'-diamine.

nitrophenyl octyl ether (o-NPOE), dioctyl phthalate (DOP), dioctyl adipate (DOA), dioctyl sebacate (DOS), potassium tetrakis( $p$-chlorophenyl)borate (KTpClPB), and tetrahydrofuran (THF), all obtained from Aldrich (City, State, Country), were used to prepare the PVC membranes. The nitrate salts of the cations (all from Merck, City, State, Country) were used without further purification, except for vacuum drying over $\mathrm{P}_{2} \mathrm{O}_{5}$. Doubly distilled water in a quartz apparatus was used to prepare all aqueous electrolyte solutions. High purity argon was used for deaeration. All experiments were carried out at room temperature. The potentials were measured by varying the concentration of $\mathrm{AgNO}_{3}$ in the test solution in a range of $1.0 \times 10^{-2}$ to $1.0 \times 10^{-7} \mathrm{M}$. The standard $\mathrm{AgNO}_{3}$ solutions were obtained by gradual dilution of $0.1 \mathrm{M} \mathrm{AgNO}_{3}$ and $\mathrm{pH}$ adjustment with Tris- $\mathrm{HNO}_{3}$ buffer.

Instrumentation. Multichannel potentiometer (Model: KST101-1) was performed with a two-electrode system. An orion double-junction $\mathrm{Ag} / \mathrm{AgCl}$ electrode supplied by $\mathrm{BAS}$ was used as the reference electrode. The Philips IS-561 electrode was used as the working electrode. An ISTEK (Model: 735p) $\mathrm{pH}$ meter was used after calibration with $\mathrm{pH}$ 4, 7, 10 solutions. All potentials were reported with respect to the $\mathrm{Ag} / \mathrm{AgCl}$ electrode at room temperature and under an argon atmosphere.

Fabrication of Electrodes. It is known that the sensitivity and selectivity of the cation selective electrode depends upon the membrane composition and the nature of the plasticizer used. ${ }^{22}$ The plasticized PVC-based membranes and electrodes were prepared by a conventional procedure. ${ }^{23,24}$ This lab made several membranes as described in Table 1. The best responding membrane $(\mathrm{m}-2)$ was prepared with a composition of $\left(N^{2} E, N^{2} E\right)-N^{2}, N^{2}$-bis(thiophen-2-ylmethylene)1,1'-binaphthyl-2,2'-diamine: $1.0 \mathrm{mg}$; PVC: $33.0 \mathrm{mg}$; DOA: $66.0 \mathrm{mg}$. The components were added in terms of weight. A homogeneous mixture was obtained after complete dissolution of all the components in THF, and then placed onto a smooth glass plate and concentrated by evaporation (THF) at room temperature. It is also known that the sensitivity, linearity, and selectivity obtained for a given ionophore depend significantly on the membrane composition and nature of plasticizer used. ${ }^{22,25}$ It is noteworthy that the lipophilicity of the plasticizer influences both the dielectric constant of the polymeric membranes and the mobility of the ionophore and its metal complex ${ }^{26,27}$ indicating that the DOA-plasticized membrane dissolves the ion association complexes and adjusts both permittivity and the ion exchanger sites mobility to give the highest possible selectivity and sensitivity. All electrodes were filled out with $0.1 \mathrm{~mol} \mathrm{~L}^{-1} \mathrm{KCl}$ as an internal filling solution.

Potentiometry. The potentiometric response measurements were carried out with a multi-channel potentiometer at room temperature. The electrochemical cell for the measurements can be represented as: $\mathrm{Ag} / \mathrm{AgCl} \mid 0.1 \mathrm{M} \mathrm{KNO}_{3} \| 0.05 \mathrm{M}$ Tris$\mathrm{HNO}_{3}$ (sample solution) $\| \mathrm{PVC}$ membrane | Internal filling solution $(0.1 \mathrm{M} \mathrm{KCl}) \mid \mathrm{AgCl} / \mathrm{Ag}$. The steady-state potential (within $0.1 \mathrm{mV}$ over a $1 \mathrm{~min}$ period) was recorded in all measurements. Conditioning of the membrane electrode was a fundamental step to achieve reliable results. The membranes were rinsed with distilled water and then conditioned for $24 \mathrm{~h}$ in $0.001 \mathrm{M} \mathrm{AgNO}_{3}$, followed by $24 \mathrm{~h}$ in $0.1 \mathrm{M} \mathrm{AgNO}_{3}$.

\section{Results and Discussion}

The Schiff base ( $\left.N^{2} E, N^{2} E\right)-N^{2}, N^{2}$-bis(thiophen-2-ylmethylene) -1,1'-binaphthyl-2,2'-diamine was employed as a silver selective ionophore in the preparation of a silver ion selective electrode. The measurements were performed in a

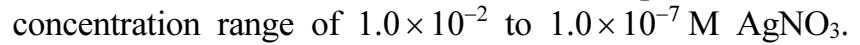
The responses of the selective four electrodes (with different plasticizer) are shown in Figure 2. Most of the electrodes containing different plasticizers exhibited a wider linear response range. The linear range, limit of detection, and slope are summarized below (Table 2).

Membrane composition has a great effect over sensitivity, selectivity, and stability of the ion selective membrane electrodes. In this study, electrodes of four different

Table 1. Membrane composition

\begin{tabular}{|c|c|c|c|c|c|c|c|}
\hline Membrane & Ionophore $^{a}$ & $\mathrm{PVC}^{a}$ & $o-\mathrm{NPOE}^{a}$ & $\mathrm{DOA}^{a}$ & $\mathrm{DOP}^{a}$ & $\operatorname{DOS}^{a}$ & $\mathrm{KT} p \mathrm{ClPBb}^{b}$ \\
\hline $\mathrm{m}-1$ & 1 & 33 & 66 & & & & 0 \\
\hline$m-2$ & 1 & 33 & & 66 & & & $\mathbf{0}$ \\
\hline$m-3$ & 1 & 33 & & 66 & & & 20 \\
\hline $\mathrm{m}-4$ & 1 & 33 & & 66 & & & 50 \\
\hline$m-5$ & 1 & 33 & & 66 & & & 100 \\
\hline$m-6$ & 1 & 33 & & & 66 & & 0 \\
\hline$m-7$ & 1 & 33 & & & & 66 & 0 \\
\hline
\end{tabular}

$a_{\text {in } \mathrm{mg} .}{ }^{b}$ in $\mathrm{mol} \%$ relative to the ionophore 


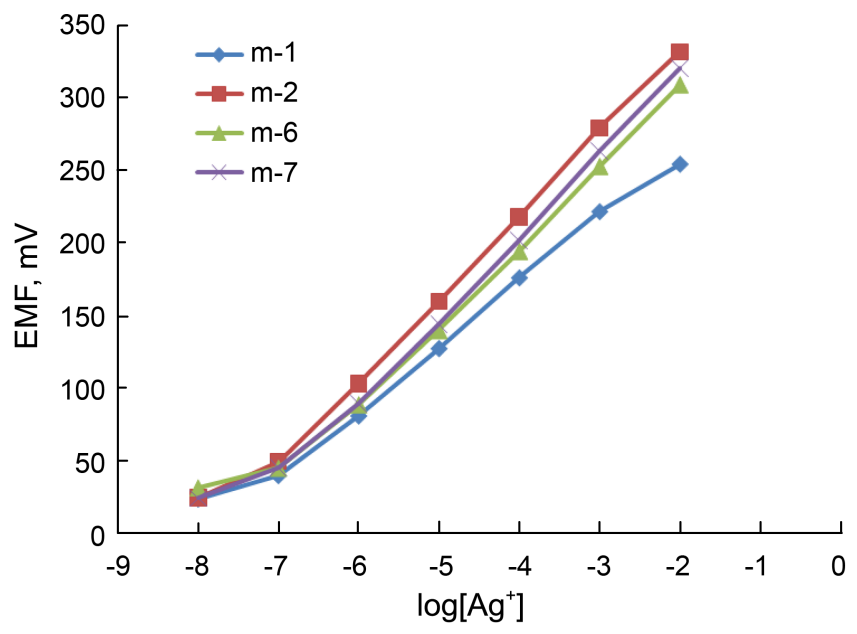

Figure 2. Potentiometric response of different membranes prepared from different plasticizers, with the ionophore towards $\mathrm{Ag}^{+}$at $\mathrm{pH} 5$.

Table 2. Linear range, limit of detection, and slope of each membrane

\begin{tabular}{cccc}
\hline Membrane & Linear range, $\mathrm{M}$ & LOD & Slope $(\mathrm{mV} / \mathrm{dec})$. \\
\hline $\mathrm{m}-1$ & $1.0 \times 10^{-3}$ to $1.0 \times 10^{-7}$ & -7.30 & 45.9 \\
$\mathbf{m}-\mathbf{2}$ & $\mathbf{1 . 0} \times \mathbf{1 0}^{-2}$ to $\mathbf{1 . 0} \times \mathbf{1 0}^{-7}$ & $-\mathbf{7 . 4 0}$ & $\mathbf{5 7 . 4}$ \\
$\mathrm{m}-3$ & $1.0 \times 10^{-2}$ to $1.0 \times 10^{-6}$ & -6.78 & 55.2 \\
$\mathrm{~m}-4$ & $1.0 \times 10^{-2}$ to $1.0 \times 10^{-6}$ & -6.75 & 51.0 \\
$\mathrm{~m}-5$ & $1.0 \times 10^{-2}$ to $1.0 \times 10^{-6}$ & -6.14 & 62.8 \\
$\mathrm{~m}-6$ & $1.0 \times 10^{-2}$ to $1.0 \times 10^{-7}$ & -7.12 & 53.4 \\
$\mathrm{~m}-7$ & $1.0 \times 10^{-2}$ to $1.0 \times 10^{-7}$ & -7.23 & 55.9 \\
\hline
\end{tabular}

compositions were prepared to identify their effects. The measurements were made in $100 \mathrm{~mL}$ of a $0.05 \mathrm{M}$ Tris- $\mathrm{HNO}_{3}$ solution in order to maintain the ionic strength of medium. The response of each electrode was measured after the addition of $\mathrm{AgNO}_{3}$ solutions, such that the $\mathrm{Ag}^{+}$ion concentrations changed from $1.0 \times 10^{-7}$ to $1.0 \times 10^{-2} \mathrm{M}$. As shown in Figure 2, all membrane electrodes responded linearly. Membrane (m-2) containing DOA had the highest Nernstian slope of all tested membranes. Considering the detection limit and slope, the $\mathrm{m}-2$ membrane provided the best results.

However, when membrane electrodes were prepared from different additive percentages, a dynamic response occurred (Figure 3). Here, m-5 (100\%), m-4 (50\%), and $\mathrm{m}-3$ (20\%) responded nearly in an identical manner, but $\mathrm{m}-2(0 \%)$ responded with an improved potential response. Only m-2 responded to the lowest test concentration of silver ions. Therefore, at low concentrations and without any additives, $\mathrm{m}-2$ was more sensitive than other membranes tested.

The proposed sensor $(\mathrm{m}-2)$ worked well under the same conditions and could be successfully employed in the potentiometric titration of $100 \mathrm{~mL}$ of $1.0 \times 10^{-3} \mathrm{M} \mathrm{Ag}^{+}$ solution with $0.01 \mathrm{M} \mathrm{NaCl}$ solution. The resulting titration curve is shown in Figure 4, indicating that the amount of $\mathrm{Ag}^{+}$ions in solution can be determine precisely from the titration curve, providing a sharp endpoint.

The $\mathrm{pH}$ of the test solution is a very important factor for

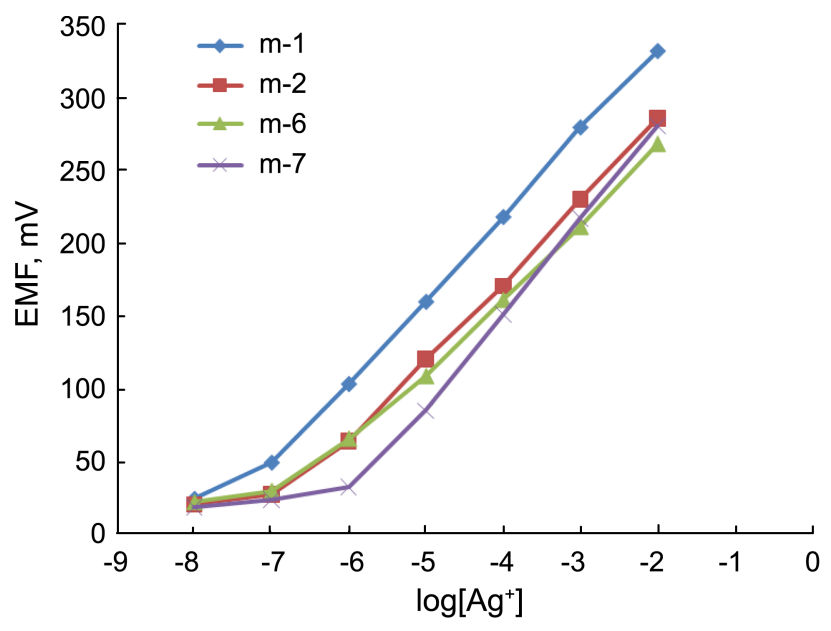

Figure 3. Potentiometric responses of membranes prepared from different amounts of additives, with the ionophore towards $\mathrm{Ag}^{+}$at pH 5.

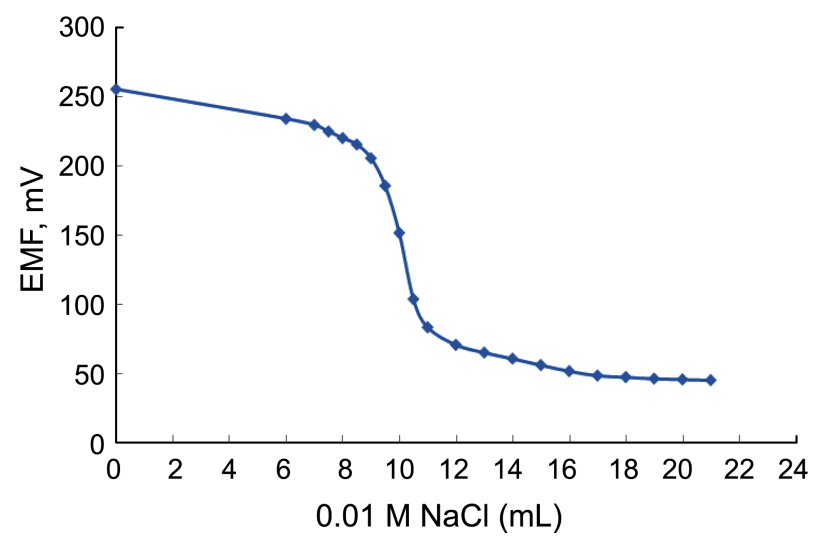

Figure 4. Plot showing the potentiometric titration of $100 \mathrm{~mL}$ of $1.0 \times 10^{-3} \mathrm{AgNO}_{3}$ with the successive addition of $1.0 \times 10^{-2} \mathrm{M}$ $\mathrm{NaCl}$ solution for $\mathrm{m}-2$.

ion selective electrodes. The $\mathrm{pH}$ response profile for the $\mathrm{m}-2$ electrode was examined using $1.0 \times 10^{-3} \mathrm{M} \mathrm{AgNO}_{3}$ in the Tris- $\mathrm{HNO}_{3}$ buffer solution. The $\mathrm{pH}$ was adjusted by introducing small drops of $0.1 \mathrm{M}$ nitric acid. The influence of the $\mathrm{pH}$ response upon the PVC membrane electrode is shown in Figure 5. As it proves, potentials were found to remain constant from $\mathrm{pH} 2$ to 6 , beyond which the potential changed considerably. After $\mathrm{pH} 6$, the potential decreased radically $(250$ to $30 \mathrm{mV})$ with a low concentration of the proton ion. The observed drift at high $\mathrm{pH}$ values might have been due to protonation of the chelating ionophore, making complexation with silver(I) impossible. Furthermore, the sensor could also be exhibiting an interference effect due to hydrogen ions. Therefore, the best performance for $\mathrm{m}-2$ was found at $\mathrm{pH} 5$.

Selectivity is perhaps the most important characteristic of any sensor, which defines the nature of the device and the extent to which it may be employed in the determination of a particular ion in the presence of other interfering ions. It is measured in terms of potentiometric selectivity coefficients, which have been evaluated using a fixed interference 


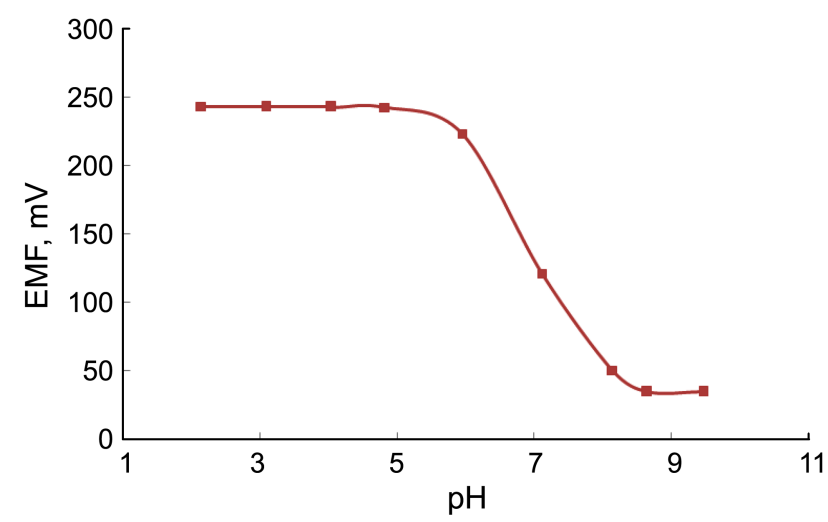

Figure 5. Effect of $\mathrm{pH}$ of the test solution $\left(1.0 \times 10^{-3} \mathrm{M}^{\circ} \mathrm{Ag}^{+}\right)$on the potential response of the $\mathrm{Ag}^{+}$ion-selective electrode $(\mathrm{m}-2)$.

method at a $1.0 \times 10^{-3} \mathrm{M}$ concentration of interfering ions. The potentiometric selectivity coefficients measure the response of the electrode for the primary ion in the presence of foreign ions. ${ }^{28}$ The results for the Schiff base $(\mathrm{m}-2)$ are shown in Table 3 . A perusal of the coefficients reveals that the sensor was selective to silver ions over the other cations. The common ions of alkali, alkaline earth metals, and transition metals would not cause any significant interference unless present at high concentrations. This Schiff-base $\left(N^{2} E, N^{2} E\right)-N^{2}, N^{2}$-bis(thiophen-2-ylmethylene)-1,1'-binaphthyl-2,2'-diamine performed primarily as a $\mathrm{Ag}^{+}$selective ionophore and avoided interference from at least 17 cited cations, a key advantage for analyzing various industrial wastewater samples. The response characteristics of the proposed PVC membrane electrode are compared with those of the best $\mathrm{Ag}^{+}$ion-selective electrodes reported earlier (Table 4).

This proposed membrane was highly selective to silver ion over a huge number of metal ion interferences and the value of selectivity coefficients were so high. For instance some comparisons have been given, ten cations were tested for interference and $\mathrm{Na}^{+}$and $\mathrm{K}^{+}$are very low. ${ }^{13}$ Thirteen cations were tested for interference and $\mathrm{Na}^{+}$and $\mathrm{Hg}^{2+}$ are very low. ${ }^{28}$

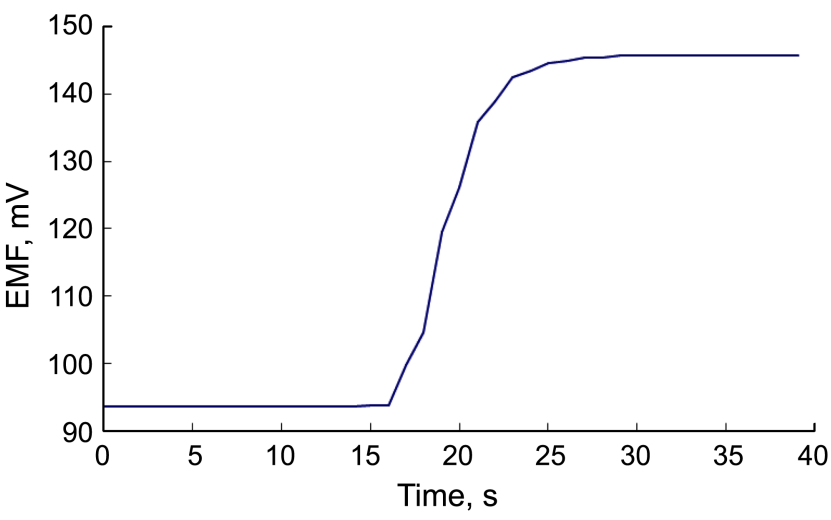

Figure 6. The static response time of $\mathrm{m}-2$ towards $1.0 \times 10^{-6}$ to 1.0 $\times 10^{-5} \mathrm{M} \mathrm{Ag}^{+}$.

Twenty cations were tested for interference but the value of selectivity coefficients are not close to our reporting. ${ }^{29}$ According to these comparisons our proposed $\mathrm{m}-2$ has shown a significant selectivity with high sensitivity.

As the concentration of silver changed from $1.0 \times 10^{-6}$ to $1.0 \times 10^{-5} \mathrm{M}$, the potential changed dynamically (Figure 6). The static response time thus obtained was less than $9 \mathrm{~s}$; however, at a concentration lower than $1.0 \times 10^{-6} \mathrm{M}$, the potential was constant. The sensing behavior of the membrane electrode remained unchanged when the potentials were recorded either from low to high concentration, or vice versa.

\section{Conclusion}

A novel Schiff-base $\left(N^{2} E, N^{2} E\right)-N^{2}, N^{2}$-bis(thiophen-2ylmethylene)-1,1'-binaphthyl-2,2'-diamine has been synthesized and finally used as PVC-based membrane sensors for potentiometric determination of silver ions. The membrane electrode (m-2), plasticized with DOA, showed better selectivity coefficients than others membrane without any additives. This proposed PVC membrane ion selective electrode exhibited a good response towards silver ions over a large concentration range of $1.0 \times 10^{-2}$ to $1.0 \times 10^{-7} \mathrm{M}$, with a

Table 3. Selectivity coefficients of various interfering ions for the membrane electrode (m-2)

\begin{tabular}{|c|c|c|c|c|c|c|c|c|c|c|c|c|c|c|c|c|c|c|c|c|}
\hline Membrar & LOD & Slope & & & & & & & & & $\operatorname{Logh}$ & $\overline{\mathrm{K}_{\mathrm{Ag}^{+}, \mathrm{j}}}$ & & & & & & & & \\
\hline \multirow{2}{*}{$\mathrm{m}-2$} & \multirow{2}{*}{-7.85} & \multirow{2}{*}{57.4} & $\mathrm{Ag}^{+}$ & $\mathrm{Hg}^{2+}$ & $\mathrm{Rb}^{+}$ & $\mathrm{K}^{+}$ & $\mathrm{Li}^{+}$ & $\mathrm{Cs}^{+}$ & $\mathrm{Cu}^{2+}$ & $\mathrm{Mg}^{2+}$ & $\mathrm{Ni}^{2+}$ & $\mathrm{Sr}^{2+}$ & $\mathrm{Pb}^{2+}$ & $\mathrm{Mn}^{2+}$ & $\mathrm{Cd}^{2+}$ & $\mathrm{Zn}^{2+}$ & $\mathrm{Ba}^{2+}$ & $\mathrm{Cr}^{3+}$ & $\mathrm{Al}^{3+}$ & $\mathrm{Na}^{+}$ \\
\hline & & & 0 & -3.7 & -4.9 & -4.9 & -4.9 & -5 & -5.4 & -6.5 & -6.3 & -6.5 & -6.4 & -6.5 & -6.4 & -6.3 & -6.5 & -5.6 & -5.9 & -5 \\
\hline
\end{tabular}

Table 4. Comparative analysis of proposed electrode with reported electrodes

\begin{tabular}{lccccc}
\hline \multicolumn{1}{c}{ Ionophore } & LOD & Slope & pH range & Response time (s) & Ref. no. \\
\hline Derivative of 4,13-diaza-18-crown-6 & $4.4 \times 10^{-8}$ & 59.3 & $3.0-8.0$ & 12 & 13 \\
Schiff-base- - tert butylcalix[4]arene & $6.3 \times 10^{-6}$ & 58.9 & $1.0-6.0$ & 30 & 28 \\
Azathioether crown & $8.0 \times 10^{-7}$ & 57.1 & $3.0-7.0$ & - & 29 \\
Hexa-thia-18-crown-6 & $4.0 \times 10^{-6}$ & 59.0 & $2.0-7.5$ & $<10$ & 30 \\
Calix[4]arene & - & 56.0 & $>2$ & - & 31 \\
Calix[2]furano[2]pyrrole & $6.0 \times 10^{-7}$ & 57.1 & - & - & 32 \\
Schiff-base $\left(N^{2} E, N^{2} E\right)-N^{2}, N^{2}$-bis(thiophen-2- & $4.0 \times 10^{-8}$ & 57.4 & $2.0-6.0$ & & This work \\
ylmethylene)-1, 1 '-binaphthyl-2,2'-diamine & & & & & \\
\hline
\end{tabular}


Nernstian slope of $57.4 \mathrm{mV} /$ dec. at $\mathrm{pH} 5$, with selectivity over 17 interfering cations. The presented electrode demonstrates an improved detection limit, response time and slope over those reported in the literature. The response time was very fast $(9 \mathrm{~s})$, with an optimal lower detection limit of $4.0 \times 10^{-8} \mathrm{M}$. This lab has shown that the fabricated electrode $(\mathrm{m}-2)$ can be employed for both residual silver and total $\mathrm{Ag}^{+}$content determination, employing only a simple procedure.

Acknowledgments. This research was supported by Basic Science Research Program through the National Research Foundation of Korea (NRF) funded by the Ministry of Education, Science and Technology (KRF-2008-313C00571).

\section{References}

1. Drake, P. L.; Hazelwood, K. J. Ann. Occup. Hyg. 2005, 49, 575.

2. Furno, F.; Morley, K. S.; Wong, B.; Sharp, B. L.; Arnold, P. L.; Howdle, S. M.; Bayson, R.; Brown, P. D.; Winship, P. D.; Reid, H. J. J. Antimicrob. Chemother. 2004, 54, 1019.

3. Burton, K. C.; Irving, H. M. N. H. Anal. Chim. Acta 1970, 52, 441.

4. Šrámková, J.; Kotrlý, S.; Jakoubková, P. Anal. Chim. Acta 2000 , 408, 183.

5. Chung, Y. S.; Barnes, R. M. J. Anal. At. Spectrom. 1998, 3, 1079.

6. Mitsuo, O.; Kiyotako, K. J. Environ. Chem. 2005, 15, 863.

7. Shim, J. H.; Jeong, I. S.; Lee, M. H.; Hong, H. P.; On, J. H.; Kim, K. S.; Kim, H-S; Kim, B. H.; Cha, G. S.; Nam, H. Talanta 2004, 63,61 .

8. Szigeti, Z.; Malon, A.; Vigassy, T.; Csokai, V.; Grün, A.; Wygladacz, K.; Ye, N.; Xu, C.; Chebny, V. J.; Bitter, I.; Rathore, R.; Bakker, E.; Pretsch, E. Anal. Chim. Acta 2006, 572, 1.

9. Ceresa, A.; Radu, A.; Peper, S.; Bakker, E.; Pretsch, E. Anal. Chem. 2002, 74, 4027.

10. Malon, A.; Vigassy, T.; Bakker, E.; Pretsch, E. J. Am. Chem. Soc. 2006, 128,8154 .
11. Wipfe, H. K.; Pioda, L. A. R.; Stefanac, Z.; Simon, W. Helv. Chim. Acta 1968, 51, 377.

12. Hutchins, R. S.; Bachas, L. G. Anal. Chem. 1995, 67, 1654.

13. Gupta, V. K.; Pal, M. K.; Singh, A. K. Anal. Chim. Acta 2009 , $631,161$.

14. Mashhadizadeh, M. H.; Shockravi, A.; Khoubi, Z.; Heidarian, D. Electroanalysis 2009, 21, 1041.

15. Sil, A.; Ijeri, V. S.; Srivastava, A. K. Anal. Sci. 2001, 17, 477.

16. Lu, J. Q.; Pang, D. W.; Zeng, X. S.; He, X. W. J. Electroanal. Chem. 2004, 568, 37.

17. Gupta, V. K.; Antonijevic, M. V.; Chandra, S.; Agarwal, S. Sensors 2002, 2, 233.

18. Bakker, E.; Buhlmann, P.; Pretsch, E. Chem. Rev. 1997, 97, 3083.

19. Ngeontae, W.; Janrungroatsakul, W.; Morakot, N.; Aeungmaitrepirom, W.; Tuntulani, T. Sens. and Actuators B: Chem. 2008, 134, 377.

20. Mahajan, R. K.; Sood, P.; Mahajan, M. P.; Shing, P. Anal. Sci. 2004, 20, 1423.

21. Colombo, F.; Benaglia, M.; Orlandi, S.; Usuelli, F. J. Mol. Cat. A: Chemical 2006, 260, 128

22. Bakker, E.; Buhlmann, P.; Pretsch, E. Electroanalysis 1999, 11, 915.

23. Craggs, A.; Moody, G. J.; Thomas, J. D. R. J. Chem. Educ. 1974, $51,541$.

24. Moody, G. J.; Oke, R. B.; Thomas, J. D. R. Analyst 1970, 95, 910.

25. Katsu, T.; Ido, K.; Takaishi, K.; Yokosu, H. Sens. Actuators B. Chemical 2002, 87, 331.

26. Bakker, E. Anal. Chem. 1997, 69, 1061.

27. Khayatian, G.; Shariati, S.; Salimi, A. Bull. Kor. Chem. Soc. 2003, $24,421$.

28. Mahajan, R. K.; Kaur, I.; Sharma, V.; Kumar, M. Sensors 2002, 2 , 417.

29. Shamsipur, M.; Javanbakht, M.; Lippolis, V.; Garau, A.; De Filippo, G.; Ganjali, M. R.; Yari, A. Anal. Chim. Acta 2002, 462, 225.

30. Mashhadizadeh, M. H.; Shamsipur, M. Anal. Chim. Acta 1999, $381,111$.

31. Chen, L.; He, X.; Zhang, H.; Liu, Y.; Hu, X.; Sheng, Y. Anal. Lett. 2001, 34, 2237.

32. Kim, S. M.; Chung, H. J.; Paeng, K-J.; Lee, C-H.; Chio, H. N.; Lee, W.-Y. Anal. Chim. Acta 2002, 453, 81. 